\title{
EMULSIFICATION USING MICROPOROUS MEMBRANES
}

\author{
Vladisavljević T. Goran, \\ Chemical Engineering Department, Loughborough University, \\ United Kingdom, \\ Vinča Institute of Nuclear Sciences, Belgrade, Serbia
}

FIELD: Chemical Technology

\begin{abstract}
:
Membrane emulsification is a process of injecting a pure dispersed phase or pre-emulsion through a microporous membrane into the continuous phase. As a result of the immiscibility of the two phases, droplets of the dispersed phase are formed at the outlets of membrane pores. The droplets formed in the process are removed from the membrane surface by applying cross-flow or stirring of the continuous phase or using a dynamic (rotating or vibrating) membrane. The most commonly used membrane for emulsification is the Shirasu Porous Glass (SPG) membrane, fabricated through spinodal decomposition in a melt consisting of Japanese volcanic ash (Shirasu), boric acid and calcium carbonate. Microsieve membranes are increasingly popular as an alternative to highly tortuous glass and ceramic membranes. Microsieves are usually fabricated from nickel by photolithography and electroplating or they can be manufactured from silicon nitride via Reactive Ion Etching (RIE). An advantage of microsieves compared to the SPG membrane is in much higher transmembrane fluxes and higher tolerance to fouling by the emulsion ingredients due to the existence of short, straightthrough pores. Unlike conventional emulsification devices such as highpressure valve homogenisers and rotor-stator devices, membrane emulsification devices permit a precise control over the mean pore size over a wide range and during the process insignificant amount of energy is dissipated as heat. The drop size is primarily determined by the pore size, but it depends also on other parameters, such as membrane wettability, emulsion formulation, shear stress on the membrane surface, transmembrane pressure, etc.

Key words: Membrane emulsification, microsieve, Shirasu Porous Glass (SPG) membrane.
\end{abstract}

\section{Introduction}

Conventional emulsification devices are high-pressure valve homogenisers, static mixers, and rotor-stator systems, such as colloid mills, stirred vessels, and toothed disc turbines [1]. In these devices, a preliminary

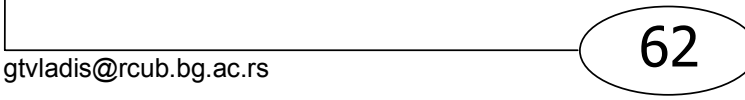


emulsified mixture, called pre-emulsion, is forced through a high-shear region near the rotor, or through valves, nozzles or baffles to promote mixing and turbulence and thereby to break up the large drops into smaller ones. This "top-down" approach does not allow a close control over the mean drop size and the drops are usually highly polydisperse. This is due to the exposure of the drops to variable shear and pressure fields, with very high shear rates near the rotor and negligible shear in "dead zones". Over the past two decades new emulsification techniques have been developed for production of emulsions directly, without a pre-emulsification step, simply by injecting a dispersed phase through micro- channels, pores and nozzles. These "bottom-up" methods include membrane emulsification [2], ink-jet printing [3], microfluidic routes [4], and microchannel emulsification [5]. They can afford uniform drops of tuneable size, because the size of the drops is controlled by the size of the pores or channels, rather than by the size of the turbulent eddies or vortices which cannot be precisely controlled. This paper reviews the latest developments in formation of emulsions using microporous membranes.

\section{Membrane emulsification (ME)}

Membrane emulsification is a process that forms emulsion by injecting a pure dispersed phase or pre-emulsion through a microporous membrane into the continuous phase. Operating methods and systems for ME are described schematically in Fig. 1.

(a) Cross flow system

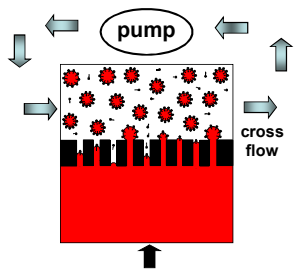

(d) Rotating flat membrane

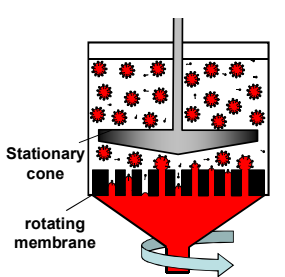

(b) Stirred cell - tube membrane

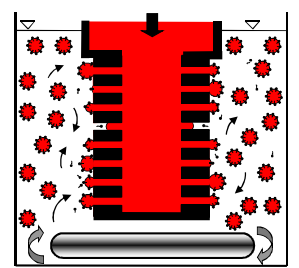

(e) Vibrating/rotating tube membrane

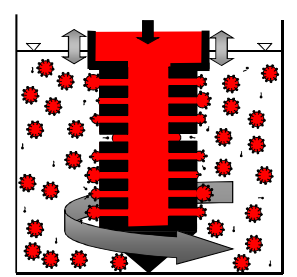

(c) Stirred cell - flat membrane

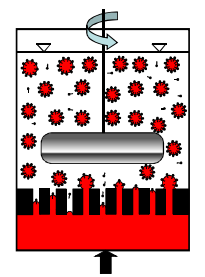

(f) Premix ME

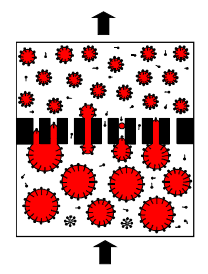

Figure 1 - Typical operating methods for membrane emulsification (ME). Slika 1 - Tipični načini izvođenja membranskog emulgovanja (ME). 


\section{Direct Membrane Emulsification (ME)}

In direct ME shown in Figs. 1(a)-(e), droplets are produced in situ by injecting a pure liquid (the dispersed phase) through the membrane into a second immiscible liquid (the continuous phase) [2]. Hydrophobic and hydrophilic membranes are needed to produce water-in-oil (W/O) and oilin-water $(\mathrm{O} N)$ emulsions, respectively. At low production rates, droplets can be formed in the absence of any shear, solely by the action of interfacial tension $[6,7]$. At small interpore distances "push-off" force as a result of droplet-droplet interactions on the membrane surface may assist in droplet detachment [8]. In order to obtain uniform droplets at higher throughputs, a shear stress is generated on the membrane surface. The size of the drops formed under shear stress on the membrane surface is a result of interplay between interfacial tension force, viscous force in the pores due to flow of the dispersed phase and drag force arising from a movement of the continuous phase relative to the drop surface. Shear stress on the membrane surface is usually generated using a cross-flow pump (Fig. 1 a) [1] or a stirrer (Figs. 1b and 1c) [9]. Cross-flow ME systems usually employ a tubular glass, ceramic or metallic membrane. The continuous phase flows inside the membrane tube, whereas the pressurised dispersed phase permeates across the membrane wall radially, from the shell side to the tube side [10]. To further increase the throughput, the continuous phase can be introduced into the membrane tube radially, thereby forming spiral streamlines in the axial direction that exert a strong centrifugal force on the inner surface of the membrane ("swirl flow") [11]. Cross-flow systems are easy to scale up and offer a constant shear rate along the membrane surface. On the other hand, stirring systems are easier to operate and a batch volume can be very small, just $10 \mathrm{~mL}$, which can be advantageous for some medical applications, e.g. preparation of emulsions loaded with anticancer drugs [12].

The shear stress can also be generated by a dynamic membrane shown in Figs. 1(d) and (e), in which case the droplet detachment from the membrane surface is facilitated by rotating [13-14] or vibrating [15-16] the membrane within the otherwise static continuous phase. In a dynamic membrane system, the shear on the membrane surface is decoupled from the cross-flow velocity. Cross flow of the continuous phase is only used to carry droplets away from the module and not to provide a surface shear. The shear is controlled by the rotational speed or the frequency and amplitude of the membrane. Thus, very low cross-flow velocities can be used and recirculation of the product stream is not necessary, which is useful to prevent secondary break-up of large droplets. Kosvintsev et al. [17] modified a commercial Weissenberg 'plate and cone' rheometer by replacing a normally impervious plate underneath the cone with the 
membrane and permitting the injection of the dispersed phase from underneath the membrane under constant shear-stress condition (Fig. 1d). It has been shown that the simple paddle-stirred cell (Fig. 1c) with a nonuniform shear profile on the membrane surface provides the same degree of drop size uniformity as the modified Weissenberg rheometer with a constant shear-stress operation [17]. Because of that, the modified Weissenberg rheometer was abandoned as a drop generation device and a simple paddle-stirred cell has become increasingly popular as a viable alternative to cross-flow ME systems. Membrane vibration through piezoactuation has been first applied by Zhu and Barrow [15] to provide extra control over droplet detachment in cross-flow ME. Holdich et al. [16] have introduced a vibrating tubular membrane system to control drop generation without any cross flow.

\section{Premix Membrane Emulsification (ME)}

In premix ME shown in Fig. 1(f), fine droplets are produced by passing a pre-emulsion through the membrane [18] or the porous bed of uniform particles [19]. If the membrane surface is wetted by the dispersed phase of the original emulsion, a phase inversion can occur during the process, leading to the formation of a W/O emulsion from an O/W premix or vice versa [20]. Another important factor for the operation of the process is the pressure difference across the membrane. If the pressure difference is lower than the capillary pressure in a pore, the droplet cannot penetrate the pore, which leads to demulsification [21] rather than homogenization of the pre-emulsion. In order to achieve additional droplet size reduction and improve droplet size uniformity, the emulsion can repeatedly be passed through the same membrane, usually up to 5 times [22-25]. Repeated membrane homogenisation was originally developed for homogenisation of large multilamellar and unilamellar lipid vesicles using track-etch polycarbonate membranes [26]. An overview of the droplet break-up mechanisms and governing process parameters in premix ME has been provided by Nazir et al. [27].

\section{Choice of membrane for ME}

The Shirasu Porous Glass (SPG) membrane is the earliest and most common membrane for $\mathrm{ME}$, manufactured from the $\mathrm{Na}_{2} \mathrm{O}-\mathrm{CaO}-\mathrm{MgO}-$ $\mathrm{Al}_{2} \mathrm{O}_{3}-\mathrm{B}_{2} \mathrm{O}_{3}-\mathrm{SiO}_{2}$ mother glass through phase separation by spinodal decomposition [1, 28-29]. The mother glass is prepared by mixing and melting Shirasu, calcium carbonate, and boric acid. Shirasu is a Japanese volcanic ash deposit from the southern Kyushu containing about $77 \%$ 
$\mathrm{SiO}_{2}$ and $10-15 \% \mathrm{Al}_{2} \mathrm{O}_{3}$ in addition to minor amounts of other inorganic oxides. After the mother glass is formed into tubes, it is treated at $650-750{ }^{\circ} \mathrm{C}$ for the period ranging from several hours to several tens of hours. This heat treatment causes the phase separation of the homogeneous glass melt into the acid-insoluble $\mathrm{Al}_{2} \mathrm{O}_{3}-\mathrm{SiO}_{2}$ phase and the acidsoluble $\mathrm{Na}_{2} \mathrm{O}-\mathrm{CaO}-\mathrm{MgO}-\mathrm{B}_{2} \mathrm{O}_{3}$ phase, as shown in Fig. 2. The phase separated glass is then immersed into a hydrochloric acid solution to dissolve the $\mathrm{Na}_{2} \mathrm{O}-\mathrm{CaO}-\mathrm{MgO}-\mathrm{B}_{2} \mathrm{O}_{3}$ phase, which results in the formation of a porous $\mathrm{Al}_{2} \mathrm{O}_{3}-\mathrm{SiO}_{2}$ skeleton with a typical porosity of $50-60 \%$. If the volume percent of the acid soluble phase is outside the above range, separation may take place by the nucleation and growth mechanism leading to the formation of discrete spherical particles of one phase surrounded by a continuous matrix of the other.

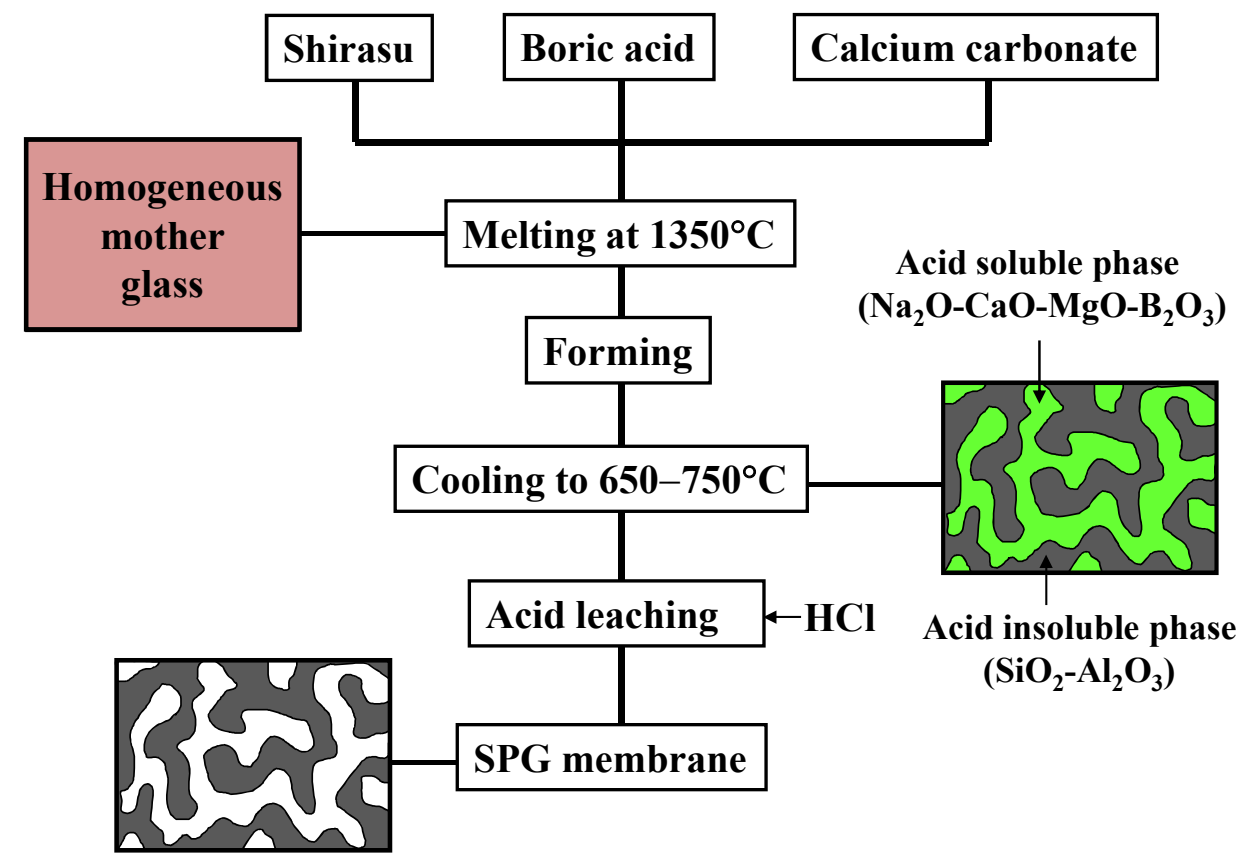

Figure 2 - Fabrication of the Shirasu Porous Glass (SPG) membrane. Slika 2 - Dobijanje membrane od Shirasu poroznog stakla (SPG)

The SPG membrane has a uniform internal structure with no voids or cracks [30] and is commercially available with a wide range of mean pore sizes $(0.050-20 \mu \mathrm{m})$ [6]. The surface of the SPG membrane can be rendered hydrophobic by a chemical modification with organosilane compounds [31] or by a physical coating process with silicone resin [32]. The SPG can 
also be made with thermoresponsive hydrophilic-hydrophobic surface properties via the layer-by-layer deposition of silica nanoparticles and grafting poly(N-isopropylacrylamide) (PNIPAM) brushes on the particle surfaces [33]. A hydraulic resistance of the SPG membrane is relatively high due to the high wall thickness of around $100 \mu \mathrm{m}$, but it can be reduced by making the membrane structure asymmetric [34]. The SPG has a higher water tolerance than the $\mathrm{VYCOR}^{\circledR}$ porous glass due to a higher $\mathrm{Al}_{2} \mathrm{O}_{3}$ content (10-15\% as compared to $0.5 \%$ of the Vycor glass). The chemical durability of the SPG against alkaline solutions is relatively poor, but can be improved by incorporating $\mathrm{ZrO}_{2}$ into the glass skeleton [35]. The alkali resistance of the SPG membrane containing $3 \mathrm{~mol} \% \mathrm{ZrO}_{2}$ in the mother glass is about 3.5 times higher than that of the conventional SPG membrane [35].

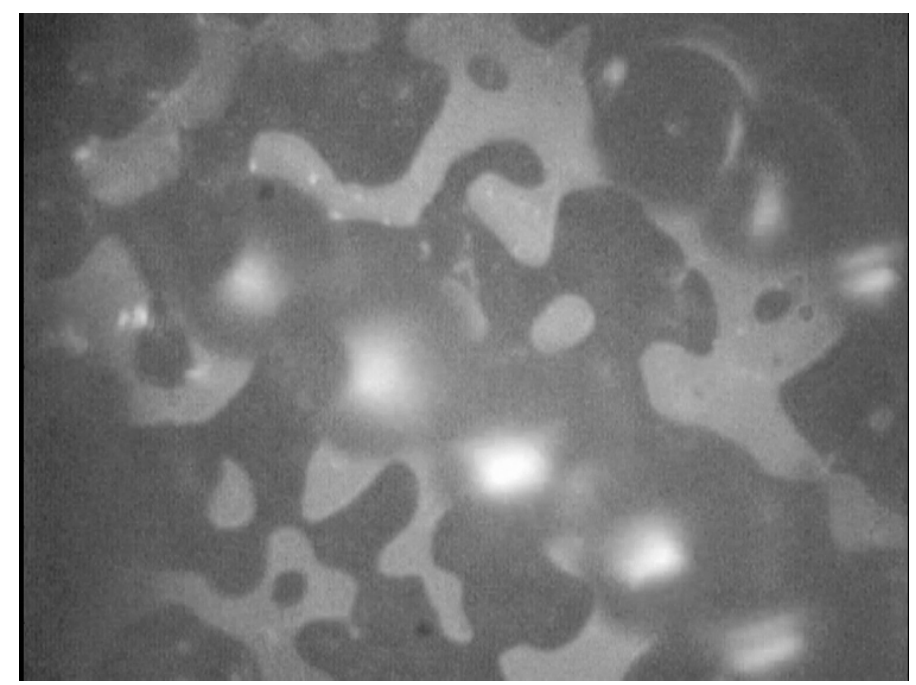

Figure 3 - Uniform droplets formed in direct ME using the SPG membrane Slika 3 - Uniformne kapi dobijene direktnim ME primenom SPG membrane

The formation of uniform oil droplets on the surface of the PG membrane is shown in Fig. 3. In direct ME, the mean droplet size is 3-4 times larger than the mean pore size of the SPG membrane and a relative span of droplet size distribution is in the range of $0.25-0.45$ [36]. A disadvantage of direct ME using the SPG membrane is that the transmembrane flux should be maintained at relatively low levels $\left(10-100 \mathrm{Lm}^{-2} \mathrm{~h}^{-1}\right)$ to avoid transition from dripping to a continuous outflow regime. Uniformly sized droplets can only be formed in the dripping regime [37-38].

In the past 10 years, microsieve membranes are increasingly being used in ME to obtain high transmembrane fluxes at low transmembrane 
pressures [39]. Microsieves are microfiltration membranes manufactured by semiconductor fabrication methods [40] Typical microsieves used for $\mathrm{ME}$ are Aquamarijn ${ }^{\mathrm{TM}}$ sieves fabricated in silicon nitride by reactive ion etching [41-43], nickel microsieves formed by electroplating (Stork Veco BV, NL and Micropore Technologies Ltd, UK [44-45, 7]) and stainless steel microsieves with laser drilled pores (Disperse Technologies Ltd, UK [46]). Because microsieves are ultra-thin foils with straight-through pores and a very low internal pore area, they are less prone to fouling by emulsion ingredients than highly tortuous SPG membranes. It is especially an important issue in pre-mix ME, because a whole emulsion, rather than a pure dispersed phase, is injected through the membrane.

The LIGA process (German acronym for LIthographie, Galvanoformung, Abformung, which means Lithography, Electroplating, and Molding) was originally developed in the early 1980s at the Karlsruhe Research Center (Forschungszentrum Karlsruhe). As shown in Fig. 4a, the UV-LIGA process consists of three main steps: UV lithography (UVL), membrane nickel electroforming and membrane release. The UVL starts with spin coating of positive photoresist on a flat conducting metal substrate. If the substrate is not electrically conductive, it should be coated with a thin layer of conductive material, such as gold. The photoresist is exposed to UV light through a mask that determines the geometry of the pores. The photoresist is then developed in a developer to remove the exposed parts of the photoresist, rinsed in deionised water and dried. The sieve is then electroformed in a nickel electrolytic plating bath to deposit a nickel film in the voids left by the removed photoresist. The nickel foil will be perforated at the regions on the substrate masked by the photoresist. Starting from a particular size of the photoresist areas on the substrate, the final perforation diameter can be adjusted as small as desired by nickel overgrowth over the masked areas in the electroplating operation. The membrane is released from the substrate by submerging in water and applying ultrasound. A pure nickel membrane is inherently hydrophobic, but can be made hydrophilic by a treatment with a wetting agent. Nickel microsieves can be produced with a variety of different pore shapes, including slotted pores [47].

The process used for fabrication of Aquamarijn ${ }^{\circledR}$ microsieves is described in Fig. 4b. It consists of four main steps: chemical vapour deposition (CVD) of a silicon nitride film on a silicon substrate, photolithography, reactive ion etching (RIE) of the silicon nitride film, and anisotropic wet etching of the silicon substrate. First, a layer of silicon nitride is deposited on the surface of a single crystal silicon substrate by CVD. This layer is formed by a reaction between dichlorosilane $\left(\mathrm{SiH}_{2} \mathrm{Cl}_{2}\right)$ and ammonia $\left(\mathrm{NH}_{3}\right)$ at elevated temperatures and low pressures. A positive photoresist is then applied to the surface of the silicon nitride film and exposed to the 
UV light through a mask. After the exposure, the photoresist is developed in a dilute $\mathrm{NaOH}$ solution to remove the exposed photoresist and form the photoresist mask having a pattern of openings. The silicon nitride exposed in these openings is etched by $\mathrm{CHF}_{3} / \mathrm{O}_{2}$ reactive ion etching (RIE) to form a pattern of pores corresponding in locations to the openings in the photoresist film. After dry etching of silicon nitride, the silicon underneath the membrane is etched by anisotropic wet etching using a $\mathrm{KOH}$ solution. Finally, the microsieve is treated with air plasma to grow a hydrophilic silicon dioxide layer on the membrane surface.

(a) Nickel microsieve

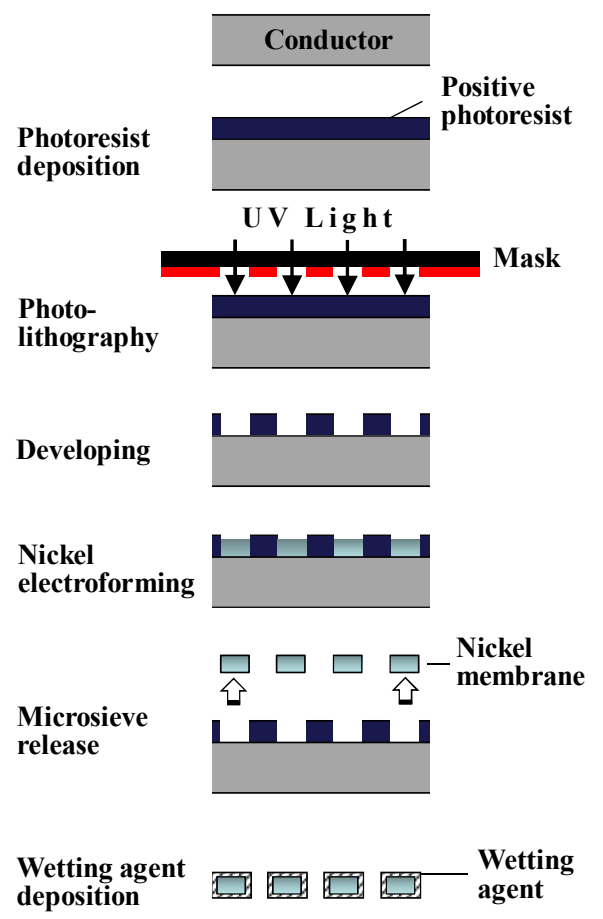

(b) Silicon nitride microsieve

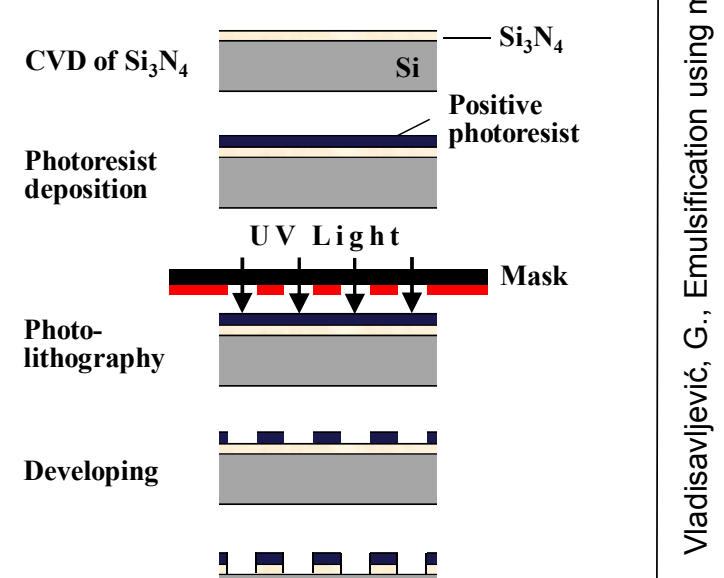

Removing the photoresist

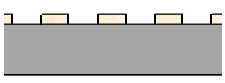

Wet etching of $\neg \square \square-\mathbf{S i}_{3} \mathbf{N}_{4}$ the Si substrate ${ }^{\beth} \square \square \square \sqsubset-$ membrane $^{2}$ Oxidation of
$\mathrm{Si}_{3} \mathrm{~N}_{4}$ surface

Figure 4 - Fabrication of microsieve membranes. Slika 4 - Dobijanje membrana od mikrosita.

Precision pores suitable for ME can also be made by pulsed laser drilling of stainless steel $[14,46]$. A focused laser beam can melt and vaporise a small area of the material to produce micropores. Pulsed lasers need to be used to prevent heating up of the surroundings of the intended pore. 


\section{Governing operating parameters in $M E$}

The effect of operating parameters on the droplet size in direct ME has been the subject of several reviews [48-53]. The major factors affecting the droplet size are microstructure and wetting properties of the membrane (pore size distribution, pore geometry, pore spacing and tortuosity), but other parameters also play an important role, such as transmembrane flux, shear stress on the membrane surface, viscosities of the continuous and dispersed phase, choice of surfactants, emulsion formulation, etc. The droplet size in ME has been predicted analytically, using several force balance and torque balance models [54-58], and computationally, using the Computational Fluid Dynamics (CFD) simulations [54, 59-60] and the Surface Evolver software [61-62].

\section{Surfactant type}

The role of surfactants in ME is to rapidly adsorb to the newly formed oil-water interface to facilitate the droplet detachment and stabilise the forming droplet by reducing the interfacial tension. The effect of dynamics of adsorption of surfactants at the liquid-liquid interface on a droplet size has been studied by several researchers [10,61, 63]. As a rule, the faster the emulsifier molecules adsorb to the newly formed interface, the smaller the droplet size of the resultant emulsion becomes. Surfactant molecules should not adsorb to the membrane surface, since otherwise the membrane can become fouled by the surfactant molecules or the dispersed phase can spread on the membrane surface. The effect of the emulsifier charge on droplet formation has been investigated by Nakashima et al. [64] for the SPG membrane and by Kobayashi et al. [65] for silicon microsieves. It has been found that surfactant molecules must not have the charge opposite to that of the membrane surface. An untreated SPG membrane has a negative surface potential of -15 to $-35 \mathrm{mV}$ in an aqueous solution at $\mathrm{pH} 2-8$, due to dissociation of acidic silanol groups $\left(\mathrm{Si}-\mathrm{OH} \leftrightarrows \mathrm{SiO}^{-}+\mathrm{H}^{+}\right)$. Hence, for this case, the use of cationic emulsifiers such as alkyl-substituted quaternary ammonium salts must be avoided. The same conclusion is valid for hydrophilic silicon microsieves, which also contain silanol groups on the surface. Zwitterionic surfactants are also unsuitable, even when they carry a net negative charge. For example, an SPG membrane can become fouled by lecithin at $\mathrm{pH} 3$ due to electrostatic interactions between positively charged groups (e.g. $-\mathrm{N}\left(\mathrm{CH}_{3}\right)_{3}{ }^{+}$or $-\mathrm{NH}_{3}{ }^{+}$) on the lecithin molecules and negatively charged silanol groups on the SPG membrane, although at $\mathrm{pH}$ 3 the net charge of lecithin molecules is negative [66]. Consequently, positively charged surfactants cannot be used in conjunction with SPG mem- 
branes and silicon microsieves. One solution to this limitation is to prepare emulsion first using nonionic or anionic surfactant and then to displace this surfactant by the surfactant with positively charged groups using the surfactant-displacement method [67].

Transmembrane pressure and wall shear stress

The minimum transmembrane pressure for driving the dispersed phase through the pores is known as the capillary pressure $P_{\text {cap }}$, and is given by the Laplace equation:

$$
P_{c a p}=\frac{4 \gamma \cos \theta}{d_{p}}
$$

where $\gamma$ is the equilibrium interfacial tension at the liquid-liquid interface, $\theta$ is the contact angle at the interfacial line between the two liquid phases and the membrane surface, and $d_{p}$ is the mean pore diameter of the membrane. The capillary pressure in premix ME is given by [68]:

$$
P_{c a p}=\frac{\gamma\left[2+2 a^{6} / \sqrt{2 a^{6}-1} \times \arccos \left(1 / a^{3}\right)-4 a^{2}\right]}{a+\sqrt{a^{2}-1}}
$$

where $a=d_{1} / d_{p}$ and $d_{1}$ is the mean droplet size in the pre-emulsion. If $d_{1} / d_{p}$ » 1 , e.g. for very large droplets, the capillary pressure is given by Eq. (1). In premix ME, the optimum transmembrane pressure is typically 10-50 times greater than the capillary pressure [23]. In direct ME using the SPG membrane, the transmembrane pressure is up to $8 P_{\text {cap }}$ and the wall shear stress is 2-40 $\mathrm{Pa}$ [37]. The higher the shear stress on the membrane surface, the higher the maximum pressure that can be applied to obtain uniform droplets. The shear stress on the membrane surface in a cross-flow system with a tubular membrane is [69]:

$$
\tau=\left(d_{i} / 4\right)\left(\Delta p_{f r} / L\right)
$$

where $d_{i}$ is the inner diameter of the membrane tube and $\Delta p_{f r}$ is the pressure drop for overcoming friction resistance in the membrane tube over a length $L$. In the case of laminar flow inside the membrane tube $\left(R e_{t}<\right.$ 2300), Eq. (3) is simplified to: $\tau=8 \eta_{c} v_{t} / d_{i}$, where $v_{t}$ is the mean velocity of the continuous phase inside the membrane tube and $\eta_{c}$ is the viscosity of the continuous phase. In the case of a turbulent flow, Eq. (3) has the form:

$$
\tau=\lambda\left(\rho_{c} v_{t}^{2} / 8\right)
$$

\section{1}


where $\rho_{c}$ is the density of the continuous phase and $\lambda$ is the friction factor, which is at 2,500 $<R e_{t}<100,000$ given by the Blasius equation:

$$
\lambda=0.3164 \mathrm{Re}_{t}^{-0.25}
$$

In ME using a stirred cell with a simple paddle stirrer, the shear stress on the membrane surface varies with the radial distance $r$ from the stirrer axis, according to the equations [70]:

$$
\begin{array}{ll}
\text { For } r<r_{\text {trans }} & \tau=0.825 \eta_{c} \omega r \frac{1}{\delta} \\
\text { For } r>r_{\text {trans }} & \tau=0.825 \eta_{c} \omega r_{\text {trans }}\left(\frac{r_{\text {trans }}}{r}\right)^{0.6} \frac{1}{\delta}
\end{array}
$$

where $\delta$ is the boundary layer thickness, $\omega$ is the angular velocity of the stirrer, and $r_{\text {trans }}$ is the transitional radius, i.e. the radial distance at which the shear stress is greatest:

$$
r_{\text {trans }}=1.23 \frac{D}{2}\left(0.57+0.35 \frac{D}{C}\right)\left(\frac{b}{C}\right)^{0.036} n_{b}^{0.116} \frac{\mathrm{Re}_{c}}{1000+1.43 \mathrm{Re}_{c}}
$$

where $D$ is the stirrer diameter, $C$ is the cell diameter, $\mathrm{b}$ is the blade height, $n_{b}$ is the number of impeller blades, and $R e_{c}$ is the Reynolds number given by $\omega \rho_{c} D^{2} /\left(2 \pi \eta_{c}\right)$.

\section{Conclusions}

Microengineering "bottom-up" strategies for emulsion formation offer a great potential in manufacturing droplets of a controlled size in a gentle manner. Membrane emulsification involves injecting a pure dispersed phase or pre-emulsion through a microfiltration membrane into the continuous phase. In order to ensure droplet detachment from the membrane surface, a shear stress is generated on the membrane surface by agitating or recycling the continuous phase in the static membrane system or vibrating/rotating the membrane in an otherwise static continuous phase. In principle, any microporous membrane can be used, but the majority of investigations have been done using the Shirasu Porous Glass (SPG) membrane and metal microsieves. The advantage of using microsieve membranes is in much higher transmembrane fluxes that can be achieved and their straight pores with a low internal surface area that do not easily become fouled by the emulsion constituents. 


\section{Acknowledgment}

The research work of G.T. Vladisavljević in membrane emulsification was sponsored by the Humboldt Foundation, The Fulbright Commission, the Japan Society of for the Promotion of Science (JSPS) (Invitation and Postdoctoral Fellowship) and the Royal Society. The support of these funding organisations is greatly appreciated.

\section{References}

[1] Karbstein, H. and Schubert H. (1995) 'Developments in the continuous mechanical production of oil-water macro-emulsions', Chem. Eng. Process., 34: 205-211.

[2] Nakashima T., Shimizu M. and Kukizaki, M. (1991) 'Membrane emulsification by microporous glass', Key Eng. Mater., 61-62: 513-516.

[3] Lub, J., Nijssen, W. P. M., Pikkemaat, J. A. and Stapert, H. R. (2006) 'Preparation of monodisperse polymer particles and capsules by ink-jet printing', Colloid. Surf. A, 289: 96-104.

[4] Teh, S. Y., Lin, Hung, L. H. and Lee, A. P. (2008) 'Droplet microfluidics', Lab Chip, 8: 198-220.

[5] Kawakatsu, T., Kikuchi, Y. and Nakajima, M. (1997) 'Regular-sized cell creation in microchannel emulsification by visual microprocessing method', J. Am. Oil Chem. Soc., 74: 317-321.

[6] Kukizaki, M. (2009) 'Shirasu porous glass (SPG) membrane emulsification in the absence of shear flow at the membrane surface: Influence of surfactant type and concentration, viscosities of dispersed and continuous phases, and transmembrane pressure', J. Membr. Sci., 327: 234-243.

[7] Kosvintsev, S. R., Gasparini, G. and Holdich, R. G. (2008) 'Membrane emulsification: Droplet size and uniformity in the absence of surface shear', J. Membr. Sci., 313: 182-189.

[8] Egidi, E., Gasparini, G., Holdich, R. G., Vladisavljević, G. T. and Kosvintsev, S. R. (2008) 'Membrane emulsification using membranes of regular pore spacing: Droplet size and uniformity in the presence of surface shear', J. Membr. Sci., 323: 414-420.

[9] Dragosavac, M. M., Sovilj, M. N., Kosvintsev, S. R., Holdich, R. G. and Vladisavljević, G. T. (2008) 'Controlled production of oil-in-water emulsions containing unrefined pumpkin seed oil using stirred cell membrane emulsification', J. Membr. Sci. 322: 178-188.

[10] Schröder, V., Behrend, O. and Schubert H. (1998) 'Effect of dynamic interfacial tension on the emulsification process using microporous, ceramic membrane', J. Colloid Interface Sci., 202: 334-340.

[11] Shimoda, M., Miyamae, H., Nishiyama, K., Yuasa, T., Noma, S. and Igura, N. (2011) 'Swirl-flow membrane emulsification for high throughput of dispersed phase flux through Shirasu porous glass (SPG) membrane', J. Chem. Eng. J., 44: 1-6. 
[12] Higashi, S. and Setoguchi, T. (2000) 'Hepatic arterial injection chemotherapy for hepatocellular carcinoma with epirubicin aqueous solution as numerous vesicles in iodinated poppy-seed oil microdroplets: clinical application of water-in-oil-in-water emulsion prepared using a membrane emulsification technique', Adv. Drug Deliv. Rev., 45: 57-64.

[13] Schadler, V. and Windhab, E. J. (2004) 'Kontinuierliches Membran-Emulgieren mittels rotierender Mikromembranen mit definierten Porenabständen', Chem. Ing. Tech., 76: 1392-1392.

[14] Vladisavljević, G. T. and Williams, R. A. (2006) 'Manufacture of large uniform droplets using rotating membrane emulsification', J. Colloid Interface Sci., 299: 396-402.

[15] Zhu, J. and Barrow, D. (2005) 'Analysis of droplet size during crossflow membrane emulsification using stationary and vibrating micromachined silicon nitride membranes', J. Membr. Sci., 261: 136-144.

[16] Holdich, R. G., Dragosavac, M. M., Vladisavljević, G. T. and Kosvintsev, S. R. (2010) 'Membrane emulsification with oscillating and stationary membranes', Ind. Eng. Chem. Res., 49: 3810-3817.

[17] Kosvintsev, S. R., Gasparini, G., Holdich, R. G., Cumming, I. W. and Stillwell, M. T. (2005) 'Liquid-liquid membrane dispersion in a stirred cell with and without controlled shear', Ing. Eng. Chem. Res., 44: 9323-9330.

[18] Suzuki, K., Shuto, I. and Hagura, Y. (1996) 'Characteristics of the membrane emulsification method combined with preliminary emulsification for preparing corn oil-in-water emulsions', Food Sci. Technol. Int. Tokyo, 2: 43-47.

[19] Yasuda, M., Goda, T., Ogino, H., Glomm, W.R. and Takayanagi, H. (2010) 'Preparation of uniform monomer droplets using packed column and continuous polymerization in tube reactor', J. Colloid Interface Sci., 349: 392-410.

[20] Suzuki, K., Fujiki, I. and Hagura, Y. (1999) 'Preparation of high concentration of $\mathrm{O} / \mathrm{W}$ and $\mathrm{W} / \mathrm{O}$ emulsions by the membrane phase inversion emulsification using PTFE membranes', Food Sci. Technol. Int. Tokyo, 5: 234-238.

[21] Koltuniewicz, A. B., Field, R. W. and Arnot T. C. (1995) 'Cross-flow and dead-end microfiltration of oily-water emulsion. Part I: Experimental study and analysis of flux decline', J. Membr. Sci., 102: 193-207.

[22] Altenbach-Rehm, J., Schubert, H. and Suzuki, K. (2002) 'Premix-Membranemulgieren mittels hydrophiler und hydrophober PTFE-Membranen zur Herstellung von O/W-Emulsionen mit enger Tropfengrößenverteilung', Chem. Ing. Tech., 74: 587-588.

[23] Vladisavljević, G. T., Shimizu, M. and Nakashima, T. (2004b) 'Preparation of monodisperse multiple emulsions at high production rates by multi-stage premix membrane emulsification', J. Membr. Sci., 244: 97-106.

[24] Vladisavljević, G. T., Shimizu, M. and Nakashima, T. (2006a) 'Production of multiple emulsions for drug delivery systems by repeated SPG membrane homogenization: Influence of mean pore size, interfacial tension and continuous phase viscosity', J. Membr. Sci., 284: 373-383.

[25] Vladisavljević, G. T., Surh, J. and McClements, D. J. (2006b) 'Effect of emulsifier type on droplet disruption in repeated Shirasu porous glass membrane homogenization', Langmuir, 22: 4526-4533. 
[26] Olson, F., Hunt, C. A. and Szoka, F. C. (1979) 'Preparation of liposomes of defined size distribution by extrusion through polycarbonate membranes', Biochim. Biophys. Acta, 557: 9-23.

[27] Nazir, A., Schroën, K. and Boom, R. (2010) 'Premix emulsification: A review', J. Membr. Sci., 362: 1-11.

[28] Nakashima T. and Shimizu M. (1986) 'Porous glass from calcium alumino boro-silicate glass', Ceramics Japan, 21: 408-412.

[29] Kukizaki, M. and Nakashima, T. (2004) 'Acid leaching process in the preparation of porous glass membranes from phase-separated glass in the $\mathrm{Na}_{2} \mathrm{O}-\mathrm{CaO}-\mathrm{MgO}-\mathrm{Al}_{2} \mathrm{O}_{3}-\mathrm{B}_{2} \mathrm{O}_{3}-\mathrm{SiO}_{2}$ system', Membrane, 29: 301-308.

[30] Vladisavljević, G. T., Kobayashi, I., Nakajima, M., Williams, R. A., Shimizu, M. and Nakashima, T. (2007) 'Shirasu Porous Glass membrane: Characterisation of microstructure by high resolution $\mathrm{x}$-ray microtomography and visualisation of droplet formation in real time', J. Membr. Sci., 302: 243-253.

[31] Kukizaki, M. and Wada, T. (2008) 'Effect of the membrane wettability on the size and size distribution of microbubbles formed from Shirasu-porousglass (SPG) membranes', Colloid Surf A, 317: 146-154.

[32] Vladisavljević, G. T., Shimizu, M. and Nakashima, T. (2005) 'Permeability of hydrophilic and hydrophobic Shirasu-porous-glass (SPG) membranes to pure liquids and its microstructure', J. Membr. Sci.: 250, 69-77.

[33] Meng, T., Xie, R., Chen, Y. C., Cheng, C. J., Li, P. F., Ju, X. J. and Chu, L. Y. (2010) 'A thermo-responsive affinity membrane with nano-structured pores and grafted poly(N-isopropylacrylamide) surface layer for hydrophobic adsorption', J. Membr. Sci., 349: 258-267.

[34] Kukizaki, M. and Goto, M. (2007a) 'Preparation and characterization of a new asymmetric type of Shirasu porous glass (SPG) membrane used for membrane emulsification', J. Membr. Sci., 299: 190-199.

[35] Kukizaki, M. (2010) 'Large-scale production of alkali-resistant Shirasu porous glass (SPG) membranes: Influence of $\mathrm{ZrO}_{2}$ addition on crystallization and phase separation in $\mathrm{Na}_{2} \mathrm{O}-\mathrm{CaO}-\mathrm{Al}_{2} \mathrm{O}_{3}-\mathrm{B}_{2} \mathrm{O}_{3}-\mathrm{SiO}_{2}$ glasses; and alkali durability and pore morphology of the membranes', J. Membr. Sci., 360: 426-435.

[36] Vladisavljević, G. T. and Schubert, H. (2002b) 'Preparation and analysis of oil-in-water emulsions with a narrow droplet size distribution using Shirasu-porous-glass (SPG) membranes', Desalination, 144: 167-172.

[37] Vladisavljević, G. T., Lambrich, U., Nakajima M. and Schubert H. (2004a) 'Production of O/W emulsions using SPG membranes, ceramic $\alpha-\mathrm{Al}_{2} \mathrm{O}_{3}$ membranes, microfluidizer and a microchannel plate: a comparative study', Colloid. Surf. A, 232: 199-207.

[38] Vladisavljević, G. T. and Schubert, H. (2003b) 'Influence of process parameters on droplet size distribution in SPG membrane emulsification and stability of prepared emulsion droplets', J. Membr. Sci., 225: 15-23.

[39] Wagdare, N. A., Marcelis, A. T. M., Ho, O. B., Boom, R. M. and van Rijn, C. J. M. (2010) 'High throughput vegetable oil-in-water emulsification with a high porosity micro-engineered membrane', J. Membr. Sci., 347: 1-7. 
[40] Brans, G., Kromkamp, J., Pek, N., Gielen, J., Heck, J., van Rijn, C. J. M., van der Sman, R. G. M, Schroën, C.G.P.H. and Boom, R. M. (2006) 'Evaluation of microsieve membrane design', J. Membr. Sci., 278: 344-348.

[41] Abrahamse, A. J., van Lierop, R., van der Sman, R. G. M., van der Padt, A. and Boom, R. M. (2002) 'Analysis of droplet formation and interactions during_cross-flow membrane emulsification', J. Membr. Sci., 204: 125-137.

[42] van Rijn, C., van der Wekken, M., Nijdam, W. and Elwenspoek, M. (1997) 'Deflection and maximum load of microfiltration membrane sieves made with silicon micromachining', J. Microelectromech. Syst., 6: 48-54.

[43] Kuiper, S., van Rijn, C. J. M., Nijdam, W. and Elwenspoek, M. C. (1998) 'Development and applications of very high flux microfiltration membranes', J. Membr. Sci., 150: 1-8.

[44] Nazir, A., Schroën, K. and Boom, R. (2011) 'High-throughput premix membrane emulsification using nickel sieves having straight-through pores', J. Membr. Sci., in press.

[45] Schadler, V. and Windhab, E. J. (2006) 'Continuous membrane emulsification by using a membrane system with controlled pore distance', 189: 130-135.

[46] Dowding, P. J., Goodwin, J. W. and Vincent, B. (2001) 'Production of porous suspension polymer beads with a narrow size distribution using a cross-flow membrane and a continuous tubular reactor', Colloid. Surf. A, 180: 310-309.

[47] Holdich, R., Kosvintsev, S., Cumming, I. and Zhdanov, S. (2006) 'Pore design and engineering for filters and membranes', Phil. Trans. R. Soc. A, 364: $161-174$

[48] Joscelyne, S. M. and Trägårdh, G. (2000) 'Membrane emulsification a literature review', J. Membr. Sci., 169: 107-117.

[49] Rayner, M. and Trägårdh, G. (2002) 'Membrane emulsification modelling: how can we get from characterisation to design?', Desalination, 145: 165-172.

[50] Charcosset, C., Limayem, I. and Fessi H. (2004) 'The membrane emulsification process - a review', J. Chem. Technol. Biotechnol., 79: 209-218.

[51] Lambrich, U. and Vladisavljević, G. T. (2004) 'Emulsification using microstructured systems', Chem. Ing. Tech., 76: 376-383.

[52] Gijsbertsen-Abrahamse, A. J., Van der Padt, A. and Boom, R. M. (2004) 'Status of cross-flow membrane emulsification and outlook for industrial application', J. Membr. Sci., 230: 149-159.

[53] Yuan, Q., Williams, R. A. and Aryanti, N. (2010) 'Innovations in high throughput manufacturing of uniform emulsions and capsules', Adv. Powder Tech., 21: 599-608.

[54] Timgren, A., Trägårdh, G. and Trägårdh, C. (2010) 'A model for drop size prediction during cross-flow emulsification', Chem. Eng. Res. Des., 88: 229-238.

[55] De Luca, G., Di Maio, F. P., Di Renzo, A. and Drioli, E. (2008) 'Droplet detachment in cross-flow membrane emulsification: comparison among torqueand force-based models, Chem. Eng. Process., 47: 1150-1158. 
[56] Christov, N. C., Danov, K. D., Danova, D. K. and Kralchevsky, P. A. (2008) 'The drop size in membrane emulsification determined from the balance of capillary and hydrodynamic forces', Langmuir, 24: 1397-1410.

[57] Williams, R. A., Peng, S. J., Wheeler, D. A., Morley, N. C., Taylor, D., Whalley, M. and Houldsworth, D. W. (1998) 'Controlled production of emulsions using a crossflow membrane', Chem. Eng. Res. Des., 76 A: 902-910.

[58] Hao, D. X., Gong, F. L., Hu, G. H., Zhao, Y. J., Lian, G. P., Ma, G. H. and Zhiguo, S. (2008) 'Controlling factors on droplets uniformity in membrane emulsification: experiment and modeling analysis', Chem. Eng. Res. Des., 47: 6418-6425.

[59] Kobayashi, I., Mukataka, S. and Nakajima, M. (2004) 'CFD simulation and analysis of emulsion droplet formation from straight-through microchannels', Langmuir, 20: 9868-9877.

[60] Abrahamse, A. J., van der Padt, A., Boom, R. M. and de Heij, W. B. C. (2001) 'Process fundamentals of membrane emulsification: Simulation with CFD', AlChE J., 47: 1285-1291.

[61] Rayner, M., Trägårdh, G. and Trägårdh, C. (2005) 'The impact of mass transfer and interfacial expansion rate on droplet size in membrane emulsification processes', Colloid Surf A, 266: 1-17.

[62] Rayner, M., Trägårdh, G., Trägårdh, C. and Dejmek, P. (2004) 'Using the Surface Evolver to model droplet formation processes in membrane emulsification', J. Colloid Interface Sci., 279: 175-185.

[63] Van der Graaf, S., Schroën, C. G. P. H., Van der Sman, R. G. M. and Boom, R. M. (2004) 'Influence of dynamic interfacial tension on droplet formation during membrane emulsification', J. Colloid Interface Sci., 277: 456-463.

[64] Nakashima, T., Shimizu, M. and Kukizaki M. (1993) 'Effect of surfactant on production of monodispersed $\mathrm{O} / \mathrm{W}$ emulsion in membrane emulsification', Kag. Kog. Ronbunshu, 19: 991-997.

[65] Kobayashi, I., Nakajima, M. and Mukataka, S. (2003) 'Preparation characteristics of oil-in-water emulsions using differently charged surfactants in straight-through microchannel emulsification', Colloid. Surf. A, 229: 33-41.

[66] Surh, J., Jeong, Y. G. and Vladisavljević, G. T. (2008), 'On the preparation of lecithin-stabilized oil-in-water emulsions by multi-stage premix membrane emulsification', J. Food Eng., 89: 164-170.

[67] Vladisavljević, G. T. and McClements, D. J. (2010) 'Modification of interfacial characteristics of monodisperse droplets produced using membrane emulsification by surfactant displacement and/or polyelectrolyte electrostatic deposition', Colloid. Surf. A, 364: 123-131.

[68] Park, S. H., Yamaguchi, T. and Nakao, S. (2001) 'Transport mechanism of deformable droplets in microfiltration of emulsions', Chem. Eng. Sci., 56: 3539-3548.

[69] Vladisavljević, G. T. and Schubert, H. (2003a) 'Preparation of emulsions with a narrow particle size distribution using microporous $\alpha$-alumina membranes', J. Dispersion Sci. Technol., 24: 811-819.

[70] Nagata, S. (1975) 'Mixing: Principles and Applications', Kodansha Ltd, Tokyo, Japan. 


\section{EMULGOVANJE PRIMENOM MIKROPOROZNIH MEMBRANA}

OBLAST: hemijske tehnologije

\section{Sažetak:}

Pri membranskom emulgovanju se čista disperzna faza ili gruba emulzija propuštaju kroz mikroporoznu membranu u kontinualnu fazu pri čemu se usled nemešljivosti dve faze, na površini membrane formiraju kapi disperzne faze. Ove kapi se odnose sa površine membrane recirkulacijom kontinualne faze iznad membrane u unakrsnom toku, mešanjem kontinualne faze ili primenom dinamičke membrane, koja može biti rotirajuća ili vibraciona. Za emulgovanje se najčešće koristi membrana od mikroporoznog stakla proizvedena procesom spinodalne dekompozicije u rastopljenoj smeši Japanskog vulkanskog pepela pod nazivom "Shirasu", krečnjaka i boroksida. U poslednje vreme se sve više koriste mikrosita od nikla proizvedena primenom fotolitografije i galvanskog niklovanja i mikrosita od silicijum nitrida, proizvedena reaktivnim jonskim nagrizanjem. Prednost mikrosita u odnosu na staklene membrane je u tome što omogućavaju veće transmembranske flukseve $i$ što se manje prljaju zbog pravih kratkih pora. U odnosu na klasično emulgovanje u emulgatorima visokog pritiska i rotor-stator uređajima, pri membranskom emulgovanju se može precizno kontrolisati srednja veličina kapi u širokom opsegu a zanemarljivo mala količina energije se rasipa u obliku toplote. Veličina kapi je prvenstveno definisana veličinom pora, ali zavisi i od kvašljivosti membrane, sastava emulzije, napona smicanja na površini membrane, transmembranskog pritiska, itd.

Ključne reči: membransko emulgovanje, mikrosito, porozna staklena Shirasu membrana.

Datum prijema članka: 25. 092011

Datum dostavljanja ispravki rukopisa: 29.09.2011.

Datum konačnog prihvatanja članka za objavljivanje: 30. 09. 2011. 